\title{
Academic Discourse and Literacy Narratives as "Equipment for Living"
}

\author{
Kris Rutten \\ Ghent University
}

Follow this and additional works at: https://docs.lib.purdue.edu/clcweb

¿

Part of the Comparative Literature Commons, and the Critical and Cultural Studies Commons

Dedicated to the dissemination of scholarly and professional information, Purdue University Press selects, develops, and distributes quality resources in several key subject areas for which its parent university is famous, including business, technology, health, veterinary medicine, and other selected disciplines in the humanities and sciences.

CLCWeb: Comparative Literature and Culture, the peer-reviewed, full-text, and open-access learned journal in the humanities and social sciences, publishes new scholarship following tenets of the discipline of comparative literature and the field of cultural studies designated as "comparative cultural studies." Publications in the journal are indexed in the Annual Bibliography of English Language and Literature (Chadwyck-Healey), the Arts and Humanities Citation Index (Thomson Reuters ISI), the Humanities Index (Wilson), Humanities International Complete (EBSCO), the International Bibliography of the Modern Language Association of America, and Scopus (Elsevier). The journal is affiliated with the Purdue University Press monograph series of Books in Comparative Cultural Studies. Contact: <clcweb@purdue.edu>

\section{Recommended Citation}

Rutten, Kris. "Academic Discourse and Literacy Narratives as "Equipment for Living"." CLCWeb: Comparative Literature and Culture 13.4 (2011): <https://doi.org/10.7771/1481-4374.1880>

This text has been double-blind peer reviewed by $2+1$ experts in the field.

The above text, published by Purdue University Press @Purdue University, has been downloaded 1812 times as of $11 /$ $07 / 19$.

This document has been made available through Purdue e-Pubs, a service of the Purdue University Libraries. Please contact epubs@purdue.edu for additional information.

This is an Open Access journal. This means that it uses a funding model that does not charge readers or their institutions for access. Readers may freely read, download, copy, distribute, print, search, or link to the full texts of articles. This journal is covered under the CC BY-NC-ND license. 


\section{PURDUE}

$\bar{U}$ N I V E R S I T Y UNIVERSITY PRESS <http://www.thepress.purdue.edu>

\section{CLCWeb: Comparative Literature and Culture}

ISSN 1481-4374 <http://docs.lib.purdue.edu/clcweb> Purdue University Press (C)Purdue University

CLCWeb: Comparative Literature and Culture, the peer-reviewed, full-text, and open-access learned journal in the humanities and social sciences, publishes new scholarship following tenets of the discipline of comparative literature and the field of cultural studies designated as "comparative cultural studies." In addition to the publication of articles, the journal publishes review articles of scholarly books and publishes research material in its Library Series. Publications in the journal are indexed in the Annual Bibliography of English Language and Literature (Chadwyck-Healey), the Arts and Humanities Citation Index (Thomson Reuters ISI), the Humanities Index (Wilson), Humanities International Complete (EBSCO), the International Bibliography of the Modern Language Association of America, and Scopus (Elsevier). The journal is affiliated with the Purdue University Press monograph series of Books in Comparative Cultural Studies. Contact: <clcweb@purdue.edu>

\begin{tabular}{c} 
Volume 13 Issue 4 (December 2011) Article 3 \\
Kris Rutten, \\
"Academic Discourse and Literacy Narratives as 'Equipment for Living'" \\
<http://docs.lib.purdue.edu/clcweb/vol13/iss3/3> \\
\hline Contents of CLCWeb: Comparative Literature and Culture 13.4 (2011) \\
<http://docs.lib.purdue.edu/clcweb/vol13/iss4/>
\end{tabular}

Abstract: In his article "Academic Discourse and Narratives of Literacy as 'Equipment for Living'" Kris Rutten discusses practices of academic discourse and argues that students entering higher education have to become part of a specific community of institutional discourse. Rutten claims that narratives of and about literacy - narratives that revolve around issues dealing with language and the acquisition of literacy - "dramatize" the tension of moving from one discourse community to another. By charting situations of "type," fictional literacy narratives can be used by students as "equipment for living" in order to reflect on confrontations and difficulties they experience in higher education. Kenneth Burke's "dramatistic pentad" is introduced as an analytical tool to study representations and interpretations of institutional discourse in fictional narratives. In a case study, the popular literacy narrative Educating Rita is analyzed and confronted with personal reflections of students. Further, Rutten discusses what can be learned from a rhetorical perspective on literacy about roles (identities) and language (institutional discourses) in higher education. 


\section{Kris RUTTEN}

\section{Academic Discourse and Literacy Narratives as "Equipment for Living"}

In literacy research, several scholars have explained students' difficulties in (higher) education as a consequence of problems with discourse in general and the confrontation of different discourses and cultural codes in particular (see, e.g., Brew; Gee; Graff; Hyland; Lea and Street; Rose; Sternglass). In new literacy studies it has been argued that the kind of "literacy" that is favored by educational institutions can be different from the "literacy" that is relevant for communities and life worlds outside of these institutions (see, e.g., Barton and Hamilton; Gee; Heath; Street). As Shirley Brice Heath puts it, students are confronted with various "ways with words" or in James Paul Gee's terms, different "ways of being in the world." I argue that fictional literacy narratives - narratives that revolve around issues dealing with language and the acquisition of literacy - "dramatize" the tension of moving from one discourse community to another and that by charting "type" situations, fictional literacy narratives can be used as "equipment for living" to reflect upon confrontations and difficulties students experience in higher education. With regard to its theoretical background, my study is based on frameworks of "academic literacies" framework with focus on the cultural and contextual situatedness of literacy in higher education (see Archer; Candlin and Plum; Jacobs; Lea and Street; Lillis and Scott; Saltmarsh and Saltmarsh) and on Kenneth Burke's "dramatistic pentad" as an analytical tool to study representations and interpretations of institutional discourse in fictional literacy narratives (on the teaching of video games as "equipment for living" see Soetaert, Bourgonjon, Rutten; on the teaching of the graphic novel as "equipment for living" see Vandermeersche and Soetaert). Further, in a case study, I present and analyze selected student responses to the film Educating Rita (Gilbert).

David Bartholomae suggests that when students enter university, they have to "invent the university ... [they have] to learn to speak our language, to speak as we do, to try on the peculiar ways of knowing, selecting, evaluating, reporting, concluding, and arguing that define the discourse of our community" (4) and in Clueless in Academe, Gerald Graff examines how academic discourse can be demystified and how students can be invited and encouraged to join academic discourse. For Graff, succeeding in higher education implies learning to think and to communicate in analytical ways, learning academic discourse, that is, learning what he calls the academic "arguespeak." The idea of arguespeak resonates with Gee's concept of Discourse (with a capital D) which he introduces to indicate that a discourse is not only restricted to language (e.g., reading and writing skills) but that it encompasses a whole way of being in the world. To become a member of a specific group, we have to learn "how to act and talk so as to take on a particular role that others will recognize" (Gee, "What is Literacy?" 1). Gee stresses that literacy is all about "language and other stuff which includes body language, gestures, actions, symbols, tools, technologies, values, attitudes, beliefs and emotions" (An Introduction 7). To participate in a discourse community we need a particular type of literacy and this means we also have to pay attention to "cultural tools" by and through which we create our identities (see Wertsch). Mary Lea and Brian Street argue that students must be able "to switch practices between one setting and another, to deploy a repertoire of linguistic practices appropriate to each setting, and to handle the social meanings and identities that each evokes" (158; see also Keroes; Soliday). However, it is also important to note that switching repertoires can create identity conflicts: "a mismatch between the social contexts which have constructed their identities in the past and the new social context which they are entering" (Ivanic 12).

A contextual and multi-level perspective on literacy can be related to what John Duffy calls the "rhetorics" of literacy ("Other Gods" 38). Duffy's concept is based on Burke's work in which the traditional conception of rhetoric as persuasion is conceptualized as a kind of symbolic action that "works to socialize [people], inducing them to identify with one another and to assent to the communicative norms of their society" (Duffy, Writing 16). From the perspective of Burke's and Duffy's concept, a rhetorical conception of literacy implies a focus on "the influence of a particular rhetoric on what writers choose to say ... to acknowledge the influence of rhetoric on what people refrain from saying and the expressive possibilities that are foreclosed to them ... the rhetorical struggles of competing peoples, cultures and institutions seeking to impose meaning and establish authority in contexts of everyday life" (Duffy, "Letters" 226-27). Thus, academic literacy can be described as a form of symbolic 
action that aims to socialize students into the specific communicative norms of the discourse community of the university.

With regard to rhetoric and literacy and as indicated above, Burke's work is relevant to my study: he described the human being as "the symbol-making, symbol-using, symbol-misusing animal" (Language 16) and he developed the theory of "dramatism" and the "dramatistic pentad" as an analytical tool to understand how these symbols work. Burke's study of rhetoric starts from an analysis of literature and drama to comment on "society and the nature of language and communication" (Brock 2). Central to his work is the understanding of culture as perceived via literary texts, and vice versa. From his analysis of literature and drama he introduced principles and methods for analyzing human symbolic action and in The Philosophy of Literary Form Burke described literary art forms such as tragedy, comedy, and satire as "equipment for living" that "size up" situations in various ways and refer to corresponding attitudes. He described literature as a specific kind of "naming" that seeks to chart "type" situations. More recently, Burke's analysis of literature as equipment for living has been extended to popular culture and the many different "narratives" or "rhetorical artefacts" that people use and create to deal with situations they encounter: "an author, poet, or political speaker puts symbols together in an essay, poem, movie, oration, or other texts as a way of trying to understand and respond to certain problems in life. Once a way of understanding and reacting to a problem is encoded in a text, that text becomes a place to which others may also turn for motivation and perceptions" (Brummett 180). These narratives should not be understood as literal and explicit prescriptions but as "a chart, a formula, manual, or map that an audience may consult in trying to decide on various courses of action" (Foss 70). Dramatistic/narrative analysis refers to a set of tools which can be used to analyze "the many meaning- and motive generating functions" (Brummett 180) performed by narratives and other symbol systems.

Based on the five basic elements of a drama, every "rounded statement about motives" (Burke, Grammar $\mathrm{xv}$ ) refers to the act (what happens), agent (the one who performs the act), scene (the setting in which an act takes place), agency (the means by which the act is carried out), and purpose (the goal or objective of the act). Burke later added a sixth term, attitude (the agent's attitude toward the act), thus changing the pentad into a hexad. These questions asking for the who, what, when, where, and why of a situation becomes more powerful when the key terms are combined to construct ratios. A ratio pairs two key terms and helps define their relation. For example, a scene-act ratio focuses on how the act is influenced by the scene. As Barry Brummett makes clear, the explanation of why some children have not acquired sufficient reading skills can start from different pentadic terms: when the underprivileged environment in which the child grew up is emphasized, we get a scene explanation, when the problem is ascribed to the fact that the child is playing videogames instead of reading books, we get an agency explanation, when the problem is ascribed to the child itself because of a lack of reading capabilities, we get an agent explanation (Brummett 186-87). Explaining an issue from a specific term of combination of terms inevitably also formulates "motives for responding to the problem ... the overall vocabulary of a text, the development of ideas or plot, the kinds of events that occur, key signs, are all studied to discover an underlying tendency to key an explanation of the world to a term or ratio" and the way a narrative "names" a situation can be studied by looking for the way in that "it suggest[s] that the world is the way it is because of a term or a ratio between terms" (Brummett 186). Further, Jerome Bruner suggests that it is "trouble" or "conflict" that drives a drama and an analysis of narratives should focus on the "trouble" that is "generated by a mismatch between two or more of the five constituents of Burke's Pentad" (697).

The theoretical background of my study is also found in Graff's work because of his suggestion that academic discourse is relevant to an audience - which he believes to be large in the U.S. interested in the culture of teaching and learning: "[this] fascination is reflected in the popularity of films like Dead Poets Society, Dangerous Minds, Educating Rita, The Mirror Has Two Faces, Good Will Hunting, Legally Blonde and countless others, as well as TV series from The White Shadow to The Education of Max Bickford" (Clueless 19). Graff's view is underlined by Janet Eldred and Peter Mortensen, who write that literacy narratives are "stories that foreground issues of language acquisition and literacy and sometimes include explicit images of schooling and teaching" (513) and Marylin McKinney and Cindy Giorgis who explore how in narratives of literacy the identities of teachers of writing in autobiographical narratives are constructed. Indeed, fictional literacy narratives (novels, plays, 
films) are used increasingly in education and thus in literacy research. James Trier, for example, analyzes student's traditional views on literacy by introducing them to a discourse oriented, socio-cultural view on literacy through the study of popular films (see also Williams and Zenger).

In what follows I present selected results from a research project in which I analyzed the literacy narrative in Educating Rita (novel and film): the project took place in the academic year 2006-2007 with 85 student subjects who matriculated recently at Ghent University. I selected Educating Rita as an exemplary literacy narrative based on a previous study in which we discussed the representation of the "literacy myth" in our (contemporary) culture of film (see Verdoodt, Rutten, Soetaert, Mottart). With regard to the degree program the said students matriculated in, the following is relevant. The degree program of a Master of Social Work and Welfare Studies at Ghent University is offered as a continuation of a Bachelor of Social Work. In contrast to the B.A. in Social Work, the M.A. in Social Work and Welfare Studies is with focus on theoretical knowledge and research. In general terms, although the students coming from the B.A. program have a background in higher education, they are neophytes to the university and more often than not they are struggling to become part of "the club" because engaging in scholarship proves challenging to students whose previous experience in higher education was professional training. In the M.A. program of Social Work and Welfare Studies a course on culture and education is taught with focus on the politics of identity using concepts from rhetoric, semiotics, and discourse analysis and it was in this course I placed Lewis Gilbert's film Educating Rita as part of the syllabus. For the theoretical background of the course I introduced Burke's concept of the dramatistic pentad and works with regard to "academic literacies" as I outline above. Class participants were required to write down their comments in the online platform of the course. First, participants were asked to interpret and evaluate the opening scene of the film: what are the themes that are dealt with, what binary oppositions are presented in the scene, what can be said about Burke's concept of scene, agents, act, agency, and purpose? Second, participants were asked to relate concepts of scene to their own personal experience. In what follows, I present selected results of the participants' responses to one of the opening scenes of the film when the Open University student Rita enters the office of the professor, Frank. Apart from focussing on the dialogues we also analyze the situation by paying attention to material aspects such as body language, clothes, furniture, architecture and so on. Next, we present a selection of our students' personal reflections.

Educating Rita was originally a stage play by Willy Russell and later became a successful film directed by Lewis Gilbert. The story is situated in England in the 1970s. There are two main characters we get to know in the opening scene as the protagonist and the antagonist of the story. Frank is a disappointed professor of literature who seems unhappy about his work and his personal life. Rita comes to his office to ask for advice. She is a hairdresser, coming from a traditional working class background, who wants to change her life by entering university. In the beginning of the film we see Rita entering an old building (the film's setting is Liverpool, but Trinity college in Dublin was used as location for filming the university scenes). Her dress does not seem appropriate: she wears a short skirt, blouse, and heels. Altogether, her dress code throughout the film differs from and is contrasted with that of other students' dress code. The focus on Frank's office is important because it is home ground for Frank, but a strange and challenging place for Rita. As she enters the room, we are confronted by Burke's scene-agent ratio and the scene-act ratio. As mentioned above, it is "trouble" that drives a drama and this trouble is generated by a mismatch between one or more of the five terms of Burke's pentad: Rita's intention to enter university and Frank's office represent a mismatch and thus trouble ensues. While the university office is the background of the act, Rita as the agent who foregrounds it by wandering around and wondering what the different objects mean. The literacy narrative is situated in a typical academic setting and the office can be described as a symbolic starting point for Rita's transition into a potential academic discourse and identity. When Rita is trying to enter the office, she is struggling with the door because of a broken handle: "FRANK. For God's sake, come in! [The door swings open revealing Rita]. RITA. [from the doorway] I'm comin' in, aren't I? It's that stupid bleedin' handle on the door. You wanna get it fixed! [She comes into the room]."

The problem Rita has with entering the office can be interpreted as a metaphor for the problems she will be confronted with by entering "the club." By focusing on Frank's office we learn about the character of the professor (scene-agent). In fact, it is Rita who directs our attention on different aspects of the room: the painting, the books, the overall view. Rita notices the picture on Frank's wall 
and surprises him by talking about it. She comments: "That's a nice picture, isn't it?" Frank says he never looks at the picture because he hardly cares about art. Rita thinks the picture is "very erotic" and stresses this by adding: "Look at those tits." In this conversation about the painting, we can see how they differ: "FRANK. [taking a look] I think it's very beautiful. RITA. I didn't ask y' if it was beautiful. FRANK. But the term 'beautiful' covers the many feelings I have about that picture, including the feeling that, yes, it is erotic." The university is presented as the scene in which transformation is possible for Rita. Apart from the university, both characters refer to other scenes which reflect the relationship between scene and other elements of the pentad. Again, there is a mismatch between the pentadic terms. Rita's purpose (getting educated) is not possible in the different scenes which play a central role in her life. When Rita is in Frank's office, she also refers to her own life, often situating her stories in particular scenes. Rita's husband does not want her to become educated, so home becomes a paradoxical scene which creates for Rita and her husband a site of struggle because they have different purposes. Apart from her home, Rita also refers to the scene where she works as a hairdresser. Again, a scene-agent ratio emerges.

Focusing on the language used in the opening scene, an agent-agency ratio emerges. In their first meeting Rita and Frank use language as a tool to communicate (agency) and to express and to present themselves (agent). Rita is confronted with conventions she does not know and Frank is surprised by Rita's unconventional attitude and we find confusion in the dialogue between Rita and Frank. The confusion is found in that both protagonists have a different cultural background. The name "Yeats," for example, evidently refers for Frank to the poet. Rita links the name "Yeats" to a wine lodge. Moreover, Rita uses dialect while at the same time she is self-assured. She seems interested in what can be said to whom in what circumstances and questions who is allowed to swear: "RITA. See, the educated classes know it's only words, don't they? It's only the masses who don't understand. I do it to shock them sometimes." Further, Rita reflects upon her own use of language and she seems deeply aware of differences in pronunciation and vocabulary between different groups of people. Rita knows how language works and how to use it to shock people. Based on Burke's pentadic concept we can define scene as the key term in Educating Rita which "controls" the other terms: agent, agency, act, and purpose. Furthermore, Rita as agent mismatches with the scene of the university which causes the trouble or conflict and that "drives the drama" (Bruner 697). Educating Rita "names" and "sizes up" the situation of a first encounter with academe by focusing on how the context influences the meaning of the utterances, the ways in which interaction changes the meanings, and the ways in which conventions and codes are used. It also problematizes the different cultural background of both characters, confronting the dominant meaning system within different scenes.

In their responses to the film, some students reflected on the power of fiction to frame what to expect from the university and how to behave. For example, "through films, I had created a kind of vague idea of what a university could be. The kind of building, the other students, the professors, the surroundings ... In fact, I expected an old and respectful building - indeed like in Educating Rita - but the buildings here are modern and cold" (all responses were written in Dutch and translated by the author of the article). Another student was confirmed in her expectations of what the university would be like: "stories of other people but also films and novels taught me what to expect from the university. For example a lecture hall. It was more or less exactly what I expected: anonymous, threatening." In their reactions these students describe an awareness of media frames and the influence of them on their expectations. They also problematize this influence by confronting these frames with their own perspectives. Next, here are selected responses by students describing themselves as agents in the scene of the university (scene-agent ratio). They focus on the confrontation between dress code, body language, and the institution. Several responses focused on the importance of clothing. One student, for example, wrote that "during my first weeks at the university I did not know what to wear. I just wanted to dress so the other students would get to know me like I really am but I also wanted to make a 'good' impression. I also realize it was important for me not to attract attention." Students also confronted the different scenes within which they have to act (scene-act ratio). One of the students who combined the course with training as teacher wrote that "clothes remain important but are not essential anymore. Yet, I realized that when I was going to have my teaching practice in a school, I would be confronted with the same problem again: what do I wear? Do I dress as a student or as a teacher? The same is true for an examination." Many participants' responses deal with prob- 
lems of how to behave in different situations (scene-agency): "I feel very insecure when I have to talk in public. I am afraid to make mistakes. Afraid of the reactions of teachers and other students. I share this feeling with most of the students. Very often teachers correct mistakes in public." By making comments and telling about personal experiences, students seem to become aware of the situated character of different types of language use. One student, for example, noted that "combining work and study is sometimes confronting. I have to switch roles. In fact this is an interesting process. After discussing Educating Rita, I became aware of the different languages I use."

When students related scenes from the film with their own experiences, they started problematizing and criticizing particular situations. For example, "watching and discussing Educating Rita made me aware that not only 'what you say' is important but also 'how you say it.' This seems unfair because some of us speak a different language and have a different vocabulary." Different institutional frameworks seem to create different role models and problems and thus some participants in the course wrote about anecdotes of interactions with different kinds of people (scene-agent ratio): "I realize that I have learned to speak different languages: with my family, with my friends, at university. Sometimes this creates difficult situations. For example: I was having lunch with my father and our professor was at the next table (close enough to overhear what we were saying). I was in doubt choosing the proper language." Some students also reflected upon specific problems with discourse in academe, thus reflecting upon the "ways with words": "when I had to write my first paper, I remember the professor said we had to check the validity of our sources. It was hard for me to understand what was meant. How do you check validity? Sometimes I find an article interesting, but I am afraid to use it." Based on the above selected responses by participants in the course, the reactions reflect on how a specific use of language, clothing, and other symbolic forms is situated within the context of the university and how this causes conflicts with their life worlds outside of the university.

The application of the theoretical framework I outline in the first section of the article and the selected responses of course participants raise several questions. For example, we have to ask ourselves if students should just transform themselves into "like-minded peers." The question is whether students can (and should) become members of the "club" just by accepting the rules. This process is complex because we can hardly list all the codes we need to participate in a particular community. Further, we can question whether we can reduce the rhetorical "moves" that count in the academe to the concrete set of templates which Graff proposes in his college writing textbook They Say, I Say: The Moves that Matter in Academe. Furthermore, the idea of education as a process of socialization into a community is also problematic because all social systems - institutions and discourses alike are always dominant meaning systems and therefore always ideological. It is not my aim in this article to solve or specifically address these issues, but I argue that we should make students aware of the fact that the "academe" is a cultural construction which is neither natural nor neutral. I concur with Duffy that a rhetorical perspective frames literacy practices dynamically by approaching literacy as a form of symbolic action that works towards identification and that socializes people into specific communicative norms. This perspective offers fertile ground for problematizing how established literacy practices are constructed and for reflecting upon "culturally diverse ways of 'doing knowledge', of 'doing school'" (Jarmon 15), and in this case, of "doing academe," that is, performing a socially meaningful role in a social situation. In the case of Educating Rita the narrative "sizes up" the confrontation of a neophyte student with academe and I postulate that this narrative can be used as equipment for living because it refers to corresponding attitudes. In the selection of students' reactions, I focused upon their comments about the scene (the university) and agency (course participants' reflection on language). As already stated above, most students reflected on how language (and other symbolic forms) can be seen as a strategic response to a specific situation. In their personal accounts students analyzed, interpreted, and problematized the codes and goals of academic literacy. In these reactions students reflected on how a specific use of language, clothing, and other symbolic forms are situated within the context of the university and how this causes conflicts with their life worlds outside of academe. Thus, discussing Educating Rita creates opportunities for reflections on the use of discourse in institutions in general and academic literacy in particular. By "dramatizing" the tension of moving from one discourse community to another, the literacy narrative of Educating Rita charts a "type" situation that students can turn to for corresponding attitudes for dealing with the (possible) problems they have in their confrontation with the world of academe. I emphasize that such a literacy narrative 
should not be viewed as a literal and explicit prescription but as "a chart, a formula, manual, or map that an audience may consult in trying to decide on various courses of action" (Foss 70). Therefore, I believe that Educating Rita can be used to reflect with students including their instructor upon the "ways with words" and "ways of being" in the academe. Furthermore, the film offers a fertile starting point for students to relate its narrative to other (more recent) literacy narratives that they might be familiar with. I believe that a dramatistic/narrative perspective can complement and extend contextual and rhetorical approaches to literacy. However, it is important to bear in mind that while Burke's dramatistic pentad originates from his textual analysis of literature, poetry, and drama, it has also been used extensively by Burke himself and by others to analyze real life events and situations; thus this use of literature suggests Steven Tötösy de Zepetnek's postulates with regard to the social relevance of the study of literature. In further research, I suggest to explore more directly how Burke's pentad can be used by students and instructors to analyze their practices of literacy by focusing on possible tensions ("trouble") between the different concepts of the pentad. By applying the pentad, we are able to focus on how entering a specific discourse community can create a "mismatch" between different social contexts and possibly cause identity conflicts.

In conclusion, the above suggested meta-perspective creates "the opportunity to explore the profound cultural force language exerts in [students'] everyday lives" (Soliday 512). Further, a rhetorical perspective "retains its association with agency and social action" (Duffy, Writing 18). As a form of symbolic action, rhetoric can also be a means to respond to and influence the institutional forces that circumscribe communicative norms (Duffy, "Letters"). Indeed, Burke's "dramatism deliberately and systematically encourages us to imagine alternative perspectives and thus new modes of action and interaction ... when we recognize that our differences and uncertainties are at least in part a consequence of our symbol-systems" (Blakesley 23). As Bruner argues, the importance of literacy narratives is based on the fact that when students try to make sense of their lives they employ the narrated version of their experiences for further reflection and practice. By reflecting upon their experiences from an interpretative perspective, students are able to not only identify with the particular academic discourse community they are engaging with but they can also "achieve narrative agency by discovering that their experience is, in fact, interpretable" (Soliday 511). From such a critical self-reflection both students and instructors can become "symbol-wise" (Enoch) about the different ways of "doing academe."

Note: The above article is an excerpt from Kris Rutten, The Rhetorical and Narrative Turn: Explorations in Education. Ph.D. diss. Ghent: Ghent U, 2010.

\section{Works Cited}

Archer, Arlene. "Cultural Studies Meets Academic Literacies: Exploring Students' Resources through Symbolic Objects." Teaching in Higher Education 13.4 (2008): 383-94.

Bartholomae, David. "Inventing the University." Journal of Basic Writing 5 (1986): 4-23.

Barton, David, and Mary Hamilton. Local Literacies: Reading and Writing in One Community. London: Routledge, 1998.

Blakesley, David. The Elements of Dramatism. New York: Longman, 2002.

Brew, Angela. "Conceptions of Research: A Phenomenographic Study." Studies in Higher Education 26.3 (2001): 271-84.

Brock, Bernard L., ed. Kenneth Burke and the 21st Century. New York: State U of New York P, 1998.

Bruner, Jerome. "Life as Narrative." Social Research 71.3 (2004): 691-710.

Brummett, Barry. Rhetoric in Popular Culture. London: Sage, 2006.

Burke, Kenneth. Language as Symbolic Action. Essays on Life, Literature and Method. Berkeley: U of California P, 1966.

Burke, Kenneth. A Grammar of Motives. Berkeley: U of California P, 1969.

Burke, Kenneth. A Rhetoric of Motives. Berkeley: U of California P, 1969.

Burke, Kenneth. The Philosophy of Literary Form. Berkeley: U of California P, 1967.

Candlin, Christopher, and Guenter Plum, eds. Researching Academic Literacies. Framing Student Literacy: Crosscultural Aspects of Communication Skills in Australian University Settings. Sydney: Macquarie U, 1998.

Duffy, John. "Letters from the Fair City: A Rhetorical Conception of Literacy." College Composition and Communication 56.2 (2004): 223-50.

Duffy, John. "Other Gods and Countries: The Rhetorics of Literacy." Towards a Rhetoric of Everyday Life: New Directions in Research on Writing, Text, and Discourse. Ed. Martin Nystrand and John Duffy. Madison: $U$ of Wisconsin P, 2003. 38-57.

Duffy, John. Writing from These Roots: Literacy in a Hmong American Community. Honolulu: U of Hawaii P, 2007. Eldred, Janet Carey, and Peter Mortensen. "Reading Literacy Narratives." College English 54.5 (1992): 512-39. 
Enoch, Jessica. "Becoming Symbol-Wise: Kenneth Burke's Pedagogy of Critical Reflection." College Composition and Communication 56.2 (2004): 272-96.

Foss, Sonja K. Rhetorical Criticism: Exploration and Practice. Illinois: Waveland P, 2004.

Gee, James Paul. An Introduction to Discourse Analysis: Theory and Method. London: Routledge, 1999.

Gee, James Paul. Situated Language and Learning: A Critique of Traditional Schooling. New York: Routledge, 2004.

Gee, James Paul. "The New Literacy Studies and the 'Social Turn'." Schools on the Web (2011): <http://www.schools.ash.org.au/litweb/page300.html>.

Gee, James Paul. "What is Literacy?" Rewriting Literacy: Culture and the Discourse of the Other. Ed. Candace Mitchell and Kathleen Weiler. New York: Bergin and Garvey, 1991. 1-11.

Gladwell, Malcolm. The Tipping Point: How Little Things Can Make a Big Difference. New York: Little, Brown \& Co, 2002.

Gilbert, Lewis, dir. Educating Rita. New York: Columbia Pictures, 1983.

Graff, Gerald. Clueless in Academe: How Schooling Obscures the Life of the Mind. New Haven: Yale UP, 2003.

Graff, Gerald. They Say/I Say: The Moves That Matter in Academic Writing. New York: Norton, 2007.

Heath, Shirley Brice. Ways with Words: Language, Life, and Work in Communities and Classrooms. Cambridge: Cambridge UP, 1983.

Hyland, Ken. Metadiscourse. London: Continuum, 2005.

Ivanic, Roz. Writing and Identity: The Discoursal Construction of Identity in Academic Writing. Amsterdam: John Benjamins, 1997.

Jacobs, Cecilia. "On being an Insider on the Outside: New Spaces for Integrating Academic Literacies." Teaching in Higher Education 10.4 (2005): 475-487.

Jarmon, Leslie (2000). "Beyond Our Comfort Zone: Twenty Countries/Fifty Majors." 10 Sep. $<$ https://webspace.utexas.edu/cherwitz/www/ie/lj.html>

Keroes, Jo. Tales out of School, Gender, Longing, and the Teacher in Fiction and Film. Carbondale: Southern Illinois UP, 1999.

Lea, Mary, and Brian Street. "Student Writing in Higher Education: An Academic Literacies Approach." Studies in Higher Education 23.2 (1998): 157-172.

Lillis, Theresa, and Mary Scott. "Defining Academic Literacies Research: Issues of Epistemology, Ideology and Strategy." Journal of Applied Linguistics 4.1 (2007): 5-32.

McKinney, Marilyn, and Cyndi Giorgis. "Narrating and Performing Identity: Literacy Specialists' Writing Identities." Journal of Literacy Research 41 (2009): 104-49.

Rose, Mike. Lives on the Boundary: A Moving Account of the Struggles and Achievements of America's Educationally Underprepared. London: Penguin, 2005.

Russell, Willy. Educating Rita. 1980. London: Longman, 2000.

Saltmarsh, David, and Sue Saltmarsh. "Has Anyone Read the Reading? Using Assessment to Promote Academic Literacies and Learning Cultures." Teaching in Higher Education 13.6 (2008): 621-32.

Soliday, Mary. "Translating Self and Differerence through Literacy Narratives." College English 56.5 (1994): 51126.

Sternglass, Marilyn. Time to Know Them: A Longitudinal Study of Writing and Learning at the College Level. Hillsdale: Lawrence Erlbaum Associates, 1997.

Soetaert, Ronald, Jeroen Bourgonjon, and Kris Rutten. "Video Games as Equipment for Living." CLCWeb: Comparative Literature and Culture 13.3 (2011): <http://docs.lib.purdue.edu/clcweb/vol13/iss3/8>.

Street, Brian. Literacy in theory and practice. Cambridge: Cambridge UP, 1984.

Tötösy de Zepetnek, Steven. "The New Humanities: The Intercultural, the Comparative, and the Interdisciplinary." Globalization and the Futures of Comparative Literature. Ed. Jan M. Ziolkowski and Alfred J. López. Thematic Section The Global South 1.2 (2007): 45-68. $\square$

Trier, James. "Reconceptualizing Literacy through a Discourses Perspective by Analyzing Literacy Events Represented in Films about Schools." Journal of Adolescent and Adult Literacy 49.6 (2006): 510-23.

Vandermeersche, Geert, and Ronald Soetaert. "Intermediality as Cultural Literacy and Teaching the Graphic Novel." CLCWeb: Comparative Literature and Culture 13.3 (2011): <http://docs.lib.purdue.edu/clcweb/vol13/iss3/20>.

Verdoodt, Ive, Kris Rutten, Ronald Soetaert, and André Mottart. "Film Choices for Screening Literacy: The 'Pygmalion Template' in the Curriculum as Contact Zone." Journal of Curriculum Studies 42.4 (2010): 519-38.

Wertsch, James V. Mind as Action. Oxford: Oxford UP, 1998.

Williams, Bronwyn, and Amy Zenger. Popular Culture and Representations of Literacy. London: Routledge, 2007.

Author's profile: Kris Rutten teaches pedagogy and cultural studies at Ghent University. In his research he explores what it implies to approach education from a rhetorical and (comparative) cultural studies perspective. His recent publications include "Narrative and Rhetoric in Social Work Education" (with André Muttart and Ronald Soetaert), British Journal of Social Work (2010) and "Film Choices for Screening Literacy: The 'Pygmalion Template' in the Curriculum as Contact Zone" (with Ive Verdoodt, Ronald Soetaert, and André Muttart), Journal of Curriculum Studies (2010), and "Intermediality, Rhetoric, and Pedagogy" (with Ronald Soetaert), CLCWeb: Comparative Literature and Culture (2011). E-mail: <kris.rutten@ugent.be> 